\title{
Extrahepatic Bile Duct Signet Ring Cell Carcinoma
}

National Cancer Institute

\section{Source}

National Cancer Institute. Extrahepatic Bile Duct Signet Ring Cell Carcinoma. NCI

Thesaurus. Code C5776.

An adenocarcinoma that arises from the extrahepatic bile ducts. It is characterized by the presence of signet ring malignant epithelial cells. 